\section{Bacteriologists lobby GMAG's first public meeting}

A LoBby for the exemption of experitechniques are used simply to rearrange the genes within $E$. coli and other bacteria made a strong protest against continuing control at GMAG's first public meeting last week.

GMAG, Britain's Genetic Manipulation Advisory Group, was fulfilling its promise to hold open meetings on its proposed new system for the risk assessment of recombinant DNA experiments (Nature 276, 104; 1978).

The new chairman of GMAG, Sir opened the meeting optimistically, saying that those who feel that GMAG's hand is too heavy "do not sufficiently allow for the depth of public interest, and how the composition of GMAG takes this into account". But all on GMAG, said Sir William "wish to improve the procedures and consult".

Those at the meeting, held on the last working day before Christmas (22 December), were mostly scientists. The consultation amounted largely to two protests from the floor: that the new scheme was difficult to operate in practice because of lack of sufficient knowledge; and that the re-arrangement of genes within a bacterium such as $E$. coli using recombinant DNA techniques (but not otherwise) must still legally be notified to the Health and safety Executive and then to GMAG, and must be carried out under Category I conditions.

These conditions, although the least ments have been disappointed. certain cases. safety committees. application worried people. ments in which recombinant DNA William Henderson (above right),

stringent of GMAG's four categories of physical containment, are still more rigorous than normal laboratory practice and can mean that the laboratory has to be modified. This type of experiment has now been exempted from control under the proposed new NIH guidelines in the US, but hopes that the new proposals in the UK would automatically exempt these experi-

Question after question from the floor drew an acknowledgment from Professor Mark Richmond of GMAG that the group would have to make a decision on this problem soon. John Maddox, one of GMAG's public interest representatives, defended the categorisation and notification of such experiments on political grounds. While accepting that the procedure for notification would be made simpler and easier, he took the view that public concern would be lessened if GMAG were seen to be controlling all experiments using recombinant DNA techniques, even though there might be scientific grounds for exemptions in

From the floor Professor R. Pritchard warned that this type of apparent illogicality undermined the credibility of the whole notification procedure in the eyes of researchers and their local

Nevertheless, the feeling of the meeting was that the new risk assessment scheme was more rational than previous guidelines. But its precise

\section{UK health ann safety: $£ 1,800$ million bill}

PREvention rather than cure, and hence research, is a major theme in the recently published annual reports of the UK's Health and Safety Commission (HSC) and Health and Safety Executive (HSE). The HSC's plans for the next five years, its report says, include epidemiological studies on populations at risk from hazardous substances; a major review of the risks to health from exposure to asbestos; the development of a policy for protecting people from the hazards of genetic engineering and working with dangerous pathogens; and research on the design safety of equipment in nuclear power reactors.

In the introduction to the HSE report John Locke, the HSE's Director General says that "research, the systematic collection and analysis of a wide range of data and the dissemination of information to all who need it" is the hallmark of the executive's efforts to reduce occupational hazards. He points out that the 16 million days lost in 1976 through accidents are estimated to have cost the country some $£ 1,800$ million. The "great majority of accidents could be prevented if simple precautions are taken" he says.

Over the past few years, the HSC's report says, there has been a reduction in the number of deaths from industrial accidents. Nevertheless, $\mathrm{Mr}$ Bill Simpson, Chairman of the commission, believes that "there is no room for complacency". Although the number of deaths has gone down, the number of notifiable accidents was 329,000 in $1977,2,000$ up on the previous year.

The commission's report also describes the preparation of draft regulations on the notification, and in some

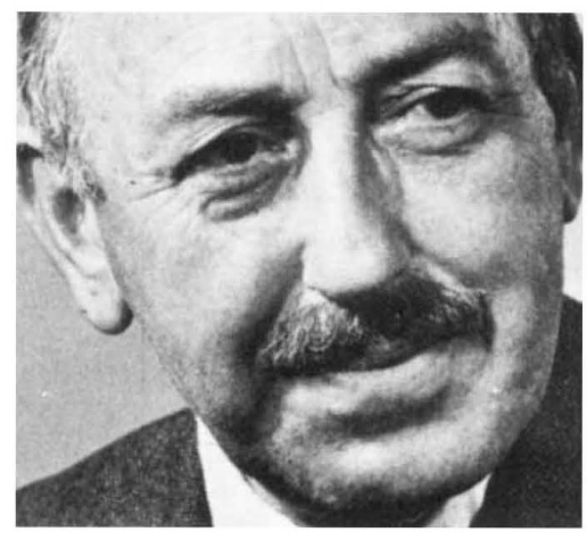

Sir William Henderson: optimistic

The most immediate problem is posed by the 'gaps' in biological knowledge which become apparent when a consistent attempt is made to calculate the risk of an experiment. For example, the causes of pathogenicity are not well understood, so one cannot estimate all the possible biological effects of a modified bacterium on the human body.

In cases like this Dr Sydney Brenner -who invented the scheme and was present at the meeting-falls back on averages. Of all known bacteria, what fraction are pathogenic? This fraction could be applied as the probability that any new bacterium were pathogenic.

Dr Peter Rigby of Imperial College, who according to Dr Brenner "has worked out a magnificent set of examples", raised the final issue: that all the calculation is in vain if the precise containment effectiveness of the four containment categories is unknown. Some claim the containment factor between categories I and IV to be $10^{12}$; some $10^{8}$. "It must be measured" said Dr Rigby, extracting a cautious commitment that GMAG act.

Eleanor Lawrence

cases survey, of installations constituting a major hazard. It comments on the regulations laid before Parliament for the packaging and labelling of about 800 dangerous chemicals in common use and discusses its efforts to change the law which exempts government controlled institutions from prosecution under health and safety legislation.

The problem of the universities and health and safety is still under review by the executive according to John Locke. The HSE is still getting to know people in the universities (heads of departments, trade unionists etc.) and identifying those sections which may present special hazards to workers or the public. Locke feels that students are the main problem because generally they are not sufficiently well trained to work in hazardous environments.

Alastair Hay 